\title{
The causal impact of material productivity on macroeconomic competitiveness in the European Union
}

\author{
Florian Flachenecker ${ }^{1}$ (D)
}

Received: 19 August 2016/Accepted: 26 December 2016/Published online: 16 January 2017

(C) The Author(s) 2017. This article is published with open access at Springerlink.com

\begin{abstract}
Interdisciplinary scholars and policy makers have claimed that increasing material productivity not only reduces environmental pressures but also improves the competitiveness of economies. This is particularly relevant in the context of the European Union (EU) since it motivates its resource efficiency and circular economy agenda by referring to this assertion. However, two limitations in the literature cast doubt on the validity of the claim. First, the literature fails to clarify the concept and measurement of macroeconomic competitiveness. Second, it lacks to take the endogeneity of material productivity into account. Addressing both shortcomings, this paper reviews the concept of macroeconomic competitiveness and identifies six conventional macroeconomic indicators to approximate it. Moreover, using panel data of the 28 member states of the EU between 2000 and 2014, the causal impact of material productivity on the six indicators is estimated, instrumenting material productivity with the number of deaths from natural hazards. The results provide evidence for a positive and causal impact of the material productivity rate on the wage rate and, with lower confidence, on the current account rate, while the remaining macroeconomic indicators are not significantly affected. Overall, these results suggest to be cautious with the claim that increasing material productivity improves macroeconomic competitiveness in the EU. Particularly the positive effect on the wage rate calls for considering possibilities to channel gains from increasing material productivity into eco-innovations to reduce the magnitude of potential rebound effects and thus environmental pressures.
\end{abstract}

Keywords Material productivity · Competitiveness · Environmental pressures · Instrument · Wages · European Union

Florian Flachenecker

florian.flachenecker.13@ucl.ac.uk

1 University College London, Bartlett School of Environment, Energy and Resources, Institute for Sustainable Resources, 14 Upper Woburn Place, London WC1H 0NN, UK 
JEL Classification $\mathrm{C} 23 \cdot \mathrm{C} 26 \cdot \mathrm{Q} 32 \cdot \mathrm{Q} 56 \cdot \mathrm{Q} 58$

\section{Introduction}

The consumption of materials is directly or indirectly part of every product or service consumed or produced in modern economies. This has led materials to be considered "the backbone of the economic production and consumption systems" (BahnWalkowiak and Steger 2015). As such, materials are on the agendas of academia, the private sector and policy making, while their role in the political process has changed over time. Initial discussions on materials emphasised their physical limits (Meadows et al. 1972; Tilton 2001), which was later complemented by environmental (Rockström et al. 2009) and strategic concerns (Graedel et al. 2012).

Starting from the early 1990s, the economic and environmental implications of material use have been recognised on a global level: "Reducing the amount of energy and materials used per unit in the production of goods and services can contribute both to the alleviation of environmental stress and to greater economic and industrial productivity and competitiveness." (UN 1992). Since then, the claim that increasing material productivity improves competitiveness while reducing environmental pressures is at the centre stage of contemporary resource efficiency, circular economy and raw materials policies in the European Union (EU) (EC 2008, 2011, 2015a). ${ }^{1}$ In particular, the environmental benefits from reducing material use and improving material productivity are reflected in a broad literature in industrial ecology (Voet et al. 2005; Kagawa et al. 2014; Wei et al. 2015) and environmental economics (Tietenberg 2000; Nakano and Managi 2012).

The interdisciplinary literature provides evidence that increasing material productivity improves competitiveness (e.g. Bleischwitz et al. 2007; Bleischwitz and Steger 2009; Schröter et al. 2011; Bassi et al. 2012) and relevant macroeconomic indicators (e.g. Distelkamp et al. 2010; Walz 2011; Meyer et al. 2011). However, there are two limitations in the current literature. First, it fails to clarify the concept and measurement of competitiveness on the macroeconomic level. Second, it lacks to take the endogeneity of material productivity into account. ${ }^{2}$ Such shortcomings are particularly relevant, as major financial resources are allocated according to previous studies (EC 2014a) and a range of environmental policies around the world are motivated by those investigations (OECD 2016; UNEP IRP 2016).

This paper first reviews the concept of macroeconomic competitiveness and identifies six conventional macroeconomic indicators to approximate it, while acknowledging that no optimal measure exists. Second, using a panel data set for the

\footnotetext{
${ }^{1}$ While this paper focusses on the EU, the OECD (2016), the UN (UNEP IRP 2011, 2014), the G7 (2015, 2016), multilateral development banks (EBRD 2015; World Bank 2015), national governments (EEA 2011), and the private sector (WBCSD 2010; McKinsey Global Institute 2011) have their own initiatives on the issue.

${ }^{2}$ A recent analysis by Sakamoto and Managi (2017) shows that better energy or environmental performance (similar to material productivity) improves the competitiveness of industries, measured in terms of their exports. The authors address the problem of endogeneity using a two-stage least square approach (2SLS).
} 
EU's 28 member states between 2000 and 2014, the causal impact of material productivity on each of the six indicators is estimated. Material productivity is instrumented with the number of deaths from natural hazards, which are shown to be both relevant and valid. The results suggest that increasing the material productivity rate causes (1) the wage rate to increase, and (2) with lower confidence, the current account rate to improve, while the other indicators are insignificantly affected. The causal impact is robust and relevant for the wage rate, raising the question whether higher wages increase or decrease competitiveness. Additionally, the paper discusses policy options to reduce the magnitude of potential rebound effects and thus environmental pressures. Overall, these findings call for more caution when making the claim that increasing material productivity improves macroeconomic competitiveness in the EU.

The paper is structured as follows. Section 2 reviews the literature on macroeconomic competitiveness and material productivity. Section 3 describes the modelling approach and instrumentation strategy in detail. Section 4 introduces the data, Sect. 5 outlines the results, Sect. 6 discusses the findings, and Sect. 7 concludes.

\section{Competitiveness and material productivity}

\subsection{Macroeconomic competitiveness}

There is no commonly agreed definition on macroeconomic competitiveness. Nevertheless, by reviewing four approaches to competitiveness, the concept is evaluated and six conventional macroeconomic indicators are identified to proxy competitiveness.

1. Krugman's critique: In two seminal papers, Krugman $(1994,1996)$ questions whether the concept of macroeconomic competitiveness is at all meaningful by bringing forward three arguments. First, countries, unlike firms, do not compete with each other on markets because they predominantly produce public goods. Additionally, countries cannot go out of business (only default) and, on average, mutually benefit from exchange. Second, if the aim is to raise the standard of living, competitiveness is essentially achieved by productivity growth. Hence, defining productivity growth as competitiveness is misleading. Third, the author warns against protectionist tendencies since proponents of competitiveness may favour imposing trade restrictions to safeguard their country from competitors.

However, Krugman (1996) acknowledges that competitiveness has some merit outside standard models: "[...] people who talk about competitiveness must understand the basics [of trade theory] and have in mind some sophisticated departure from standard economic models, involving imperfect competition, external economies, or both." Therefore, proponents of macroeconomic competitiveness typically refer to any types of market failures, including imperfect information, market power, and transaction costs (Reinert 1995; 
Budzinski 2007; Fagerberg et al. 2007). For instance, Lall (2001) argues that countries can generate a competitive advantage temporarily by grasping benefits from correcting market failures faster than others. In a nutshell, the concept of macroeconomic competitiveness becomes a meaningful concept according to Krugman (1996) once market failures are present.

2. Price competitiveness: Among economists and policy makers, macroeconomic competitiveness is frequently measured by standard cost and trade indicators, including unit labour costs, the real effective exchange rate, interest rates, and the current account (Siggel 2006). The rationale is that competition plays out on prices, essentially resulting in offshoring production and employment from high-cost to low-cost economies (Acemoglu et al. 2016). For high-cost countries to remain competitive, they need to reduce costs (Salvatore 2010). However, Porter (1990) argues that such cost measures are insufficient in explaining a competitive advantage. For instance, a fall in wages or the exchange rate does not make a country more competitive if competitiveness is defined as raising the standard of living (Snowdon and Stonehouse 2006). Aiginger (2006) argues that 'price competitiveness' is a reasonable measure in perfectly competitive markets and for low-income countries since they are competing along homogeneous goods, but not in imperfect markets and highincome countries, as they typically compete along innovations, qualities as well as environmentally sustainable and socially inclusive growth (Rozmahel et al. 2014). ${ }^{3}$

Consequently, price measures are important in determining competitiveness, but are insufficient and potentially misleading if they are not complemented by non-price indicators. Accordingly, Aiginger (2006) defines competitiveness as "the ability of a country or location to create welfare", which is shared by several scholars (Reinert 1995; Lehner et al. 1999; Snowdon and Stonehouse 2006; Salvatore 2010; Voinescu and Moisoiu 2015). To measure welfare, Aiginger (2006) argues to complement cost measures with additional non-price factors, including outcome measures (e.g. GDP per capita, employment, wages) and process measures (e.g. institutions, technology).

3. Porter's diamond: Porter (1990) argues that competitiveness can only be realised by firms through continuous innovation and upgrading. This approach essentially claims that only firms compete with each other, but the country's environment is an important factor for firms' success. In short, microeconomic and macroeconomic factors combined determine competitiveness (Thompson 2004). Porter (1990) calls these the "diamond of national competitiveness", which comprises interrelated factors that together explain macroeconomic

\footnotetext{
3 This has previously been discussed in the literature as the Kaldor paradox which originates from relative unit labour costs being positively correlated with the relative market share of manufacturing exports (Kaldor 1978). Hence, Kaldor (1978) questioned "the relative importance of price (or cost?) competition, as against other 'non-price' factors, such as superiority of design or quality, length and reliability of delivery dates, after-sales service, etc.".
} 
competitiveness. ${ }^{4}$ Hence, competitiveness is essentially about setting the business and legal environment in which firms compete.

4. Institutions: There are many definitions of institutions (North 1990, 1991; Coase 1998; Bleischwitz 2005). Nevertheless, the consensus in the literature seems to be that institutions directly or indirectly establish constraints to the economic system, thus shaping the 'rules of the game'. According to Caplin and Nalebuff (1997), institutions have an impact on their environment by shaping the formal, informal, internal, and external setting in which firms operate, i.e. institutions are a determinant of competitiveness. As such, institutions are thought to support factor accumulation, innovation, the efficiency of resource allocation and thus affecting economic growth and development (de Soto 2003; Lee 2010). Furthermore, institutions can incentivise the spread of knowledge by influencing its content, direction, and dynamic (Vanberg and Kerber 1994) which is at the core of Schumpeterian competition (Budzinski 2007). ${ }^{5}$ In short, institutions play an important role in the competitiveness debate since they shape the environment in which firms operate, both internally and externally (Bleischwitz 2003, 2010).

Considering these four approaches, the following understanding and indicators are identified to best approximate macroeconomic competitiveness. First, the existence of market failures is a necessary condition for macroeconomic competitiveness. Second, price measures need to be complemented by non-price factors. Third, country level indicators need to be linked with firm level measures. Fourth, competitiveness is about generating welfare. Accordingly, following Dechezleprêtre and Sato (2014), six indicators are chosen to approximate the various understandings of macroeconomic competitiveness: (1) gross domestic product (GDP) per capita, (2) the unemployment rate, (3) wages per capita (all three reflecting the ability of an economy to generate welfare), (4) research and development (R\&D) investments referring to Porter's concept of continuous innovation and upgrading, (5) the current account representing a conventional price competitiveness indicator, and (6) the Global Competitiveness Index (GCI) from the World Economic Forum that emphasises the role of institutions as a determinant of competitiveness. While these six indicators are argued to approximate macroeconomic competitiveness, it has to be acknowledged that no optimal measure (or set of measures) exists. Thus,

\footnotetext{
${ }^{4}$ Porter (1990) identifies four factors. First, factor conditions such as labour, capital, land, resources, highly specialised skills, and infrastructure, which determine which goods and services a country specialises in and how competitive they can be supplied to the market. Second, demand conditions, which describe the sophistication of domestic demand and is positively linked to competitiveness. Third, related and supported industries, including the strength, proximity and specialisation of the domestic supplier industry to increase the likelihood of innovation spill-overs (due to proximity, clusters, networks, preferential treatment). Fourth, firm strategy, structure, and rivalry, which emphasise the importance of the legislative environment, the creation, organisation, and management of firms as well as the level of competition in the market.

5 At the same time, Bleischwitz (2005) argues that institutions face a trade-off between setting rules, which can decrease transaction costs and lead to an efficient allocation of resources, and the cost of setting up and maintaining institutions as well as the costs of 'over-regulation', for instance when outdated regulation impedes technological progress.
} 
this analysis brings forward one possible set of indicators based on reviewing the literature, without claiming to capture all aspects of it.

\subsection{Material productivity}

Productivity is typically represented as the ratio between the output of a production process and its inputs (OECD 2007). Material productivity is a single-factor productivity indicator and measures the effectiveness by which output has been created from each unit of material input (Dahlstrom and Ekins 2005; Syverson 2011), and can be expressed the following way.

$$
M P_{t, i}=\frac{Y_{t, i}}{M_{t, i}}
$$

where $Y$ represents output, $M$ material input or material use $\left(M_{t, i}>0\right), t$ the time dimension, and $i$ the level dimension (country, firm). The concept of material productivity has been increasingly standardised, used in the academic literature (e.g. Bruyn et al. 2009; Steinberger and Krausmann 2011; Wiedmann et al. 2015) and taken up in a number of statistical offices in industrial countries such as across the EU and Japan (Hinterberger et al. 2003; Bahn-Walkowiak and Steger 2015). Similarly, several reports from international organisations refer directly to it (e.g. UNEP IRP 2011, 2014; OECD 2016).

\section{Modelling approach}

\subsection{The problem of endogeneity}

There are three sources of endogeneity_omitted variable bias, reverse causality, and measurement errors. The latter can be problematic if there are additive random errors. Since the EU has established monitoring and reporting authorities, any timeinvariant and arbitrary measurement errors are unlikely to occur. But even if measurement errors exist in the sample, two-stage least square (2SLS) would address this problem provided that the instrument is uncorrelated with the additive random error (Angrist and Krueger 2001).

The second source of endogeneity is omitted variable bias. Without controlling for all possible variables that influence competitiveness, the coefficients are biased using ordinary least square (OLS). 2SLS can be a viable solution to this problem, even if the possible variables causing the bias are unknown. This is because the instrument only considers the part of the variation in the endogenous variable that is uncorrelated with the omitted variables, assuming that the instrument is indeed exogenous (Angrist and Krueger 2001).

The third source of endogeneity is reverse causality, which will be the focus of this paper. Even though increasing material productivity is argued to improve 
competitiveness, ${ }^{6}$ competitiveness in turn is likely to affect material productivity, as more competitive countries are more likely to be more material productive (Bringezu et al. 2004). This is because they are technologically further advanced and they generate more (eco-)innovations which can increase material productivity (Bleischwitz et al. 2007). Additionally, the following outlines the rationale for reverse causality for each competitiveness indicator individually.

Material productivity is argued to have a positive impact on economic growth and (un)employment (Walz 2011; Meyer et al. 2011; Cooper et al. 2016), while growth endogenously determines material productivity. High employment figures positively affect economic growth through the production function of an economy and material consumption by increased disposable income for purchasing material-intensive goods. Disposable income is closely related to wages, which determine the cost of labour and thus the use of materials, as labour and materials are argued to be substitutes (Bruyn et al. 2009; Allwood et al. 2011; Bleischwitz 2012). Additionally, wages are considered to impact economic growth and trade (Cahuc and Michel 1996; Askenazy 2003). While there is no evidence so far that material productivity has an effect on wages, according to conventional theory, labour productivity determines wages (Millea 2002). In the case of $R \& D$, some economic models predict increasing material productivity triggers investments in $R \& D$, especially in eco-innovations (Meyer 2011). At the same time, R\&D efforts can result in increased material productivity (Eco-Innovation Observatory 2012). Material and energy productivity are claimed to have a positive impact on trade and thus the current account (UNIDO 2011), while trade and the current account endogenously determine material productivity, both through general trade (as part of GDP) and the trade of materials (as part of material use). Lastly, material productivity is correlated with composite competitiveness indicators such as the GCI (Bleischwitz et al. 2009); however, the direction of the causal effect is unclear.

All such reverse effects are highly problematic, because the coefficients of correlation and simple regression analyses become biased and inconsistent (Angrist and Pischke 2009). Thus, 2SLS is used addressing all three sources of endogeneity (Angrist and Krueger 2001). Alternative methods such as testing for causality (e.g. co-integration testing), using lagged endogenous variables, and dynamic panel approaches are either merely a form of predictive causality or are likely to violate

\footnotetext{
${ }^{6}$ Bleischwitz and Steger (2009) find a positive and significant correlation between material productivity and several competitiveness indices. An investigation on the savings potential of increasing material efficiency in SMEs in Germany suggests that the average savings are in the order of 7-8\% (Fh-ISI et al. 2005; Schröter et al. 2011). This positive link between material productivity and competitiveness is also reflected in related studies on energy efficiency (UNIDO 2011; EC 2014b), resource efficiency (Oakdene Hollins 2011; OECD 2011; Bassi et al. 2012; AMEC and Bio IS 2013), and environmental efficiency (Sakamoto and Managi 2017). Material productivity is argued to improve the macroeconomic environment. Scholars find evidence that material productivity increases GDP (Distelkamp et al. 2010; Meyer et al. 2011; EC 2014c), employment (Distelkamp et al. 2010; Meyer 2011; Walz 2011; Meyer et al. 2011; EC 2014c; Cooper et al. 2016), and total factor productivity (Ecorys 2011), while reducing public debt (Distelkamp et al. 2010; Meyer et al. 2011) and absolute material consumption (Distelkamp et al. 2010; Meyer et al. 2011). Material productivity also leads to more environmentally sustainable economies (Zhang and London 2013; Aiginger and Vogel 2015). Whether there is a causal impact of increasing material productivity on competitiveness has not yet been researched, notwithstanding initial attempts (Flachenecker 2015).
} 
the exclusion restriction (Kraay 2012; Panizza and Presbitero 2014). Reed (2015) additionally shows that even using lagged variables as instruments can be problematic in case they explain the dependent variable. Hence, using an exogenous variable as an instrument is the most adequate way to address all three causes of endogeneity.

\subsection{Instrumentation strategy}

Instruments have to comply with two conditions-they need to be relevant and valid. The former essentially requires a strong correlation between the instrument and the endogenous variable. The impact of natural hazards on material productivity can occur both through changes in output and material use. While there is no consensus on either the magnitude or the direction of how natural hazards affect output (Cavallo et al. 2010; World Bank 2010; Cavallo et al. 2013; Noy and DuPont 2016), the great majority of the literature argues that disasters reduce economic activity due to damages to the capital stock and other disruptions in the immediate aftermath of the disaster (e.g. electricity cuts, obstructing people to work) as well as in long term (e.g. crowding-out investments, migration, welfare transfers) (Hochrainer 2009; Raddatz 2009; Hsiang and Jina 2014; DuPont et al. 2015). Material use is likely to be positively affected by disasters as a result of reconstruction efforts, which might take place right after the disaster struck or with a delay.

The impact of such disasters on material productivity can be exemplified by the heat wave in Europe in 2003. Many European countries were hit by an unusually severe heat wave in July-August that year, causing a total of more than 70,000 deaths across 16 countries (Robine et al. 2008). The heat wave had substantial economic consequences relevant for both output and material use, e.g. river transportation was restricted because of low water levels, electricity production was reduced since nuclear power plants had to shut down, public rail transportation was disrupted, construction efforts were paused and later caught up, and total agriculture production decreased by approximately 10\% (Ciais et al. 2005). The number of deaths during 2003 was unprecedented and concentrated mainly in Italy, France, Spain, Germany, Belgium, and Portugal. Nevertheless, every country in the sample experiences deaths from natural hazards across time.

Disasters have previously been used as instruments for economic variables such as trade, aid inflows and oil income (Ramsay 2011; Felbermayr and Gröschl 2013; Jackson 2014), but not for any productivity measure. Kahn (2005) argues that 'natural' disasters occur exogenously and it is unlikely that an economy's sensitiveness to disasters changes in the short run (World Bank 2010). Since panel data are used that spans over 15 years, controls for improvements in the resistance to disasters over time are needed. Kahn (2005) finds that the general level of economic development, institutional quality, and geography affects the consequences of natural hazards. Therefore, country-specific trends are added and the model is estimated in first-difference, which remove stable transitory developments and the impact of time-invariant features, such as economic development and institutional quality. 
Since a fixed effects model is estimated in first difference, the instrument needs to vary over time. The number of deaths from natural hazards is chosen to instrument for material productivity since the variable varies, both across countries and time. Since this variable covers a variety of disasters (floods, storms, droughts, etc.), they are likely to occur in various parts of each country, thus reducing the possibility that re-occurring events systematically alters the effect on material productivity. Additionally, the number of deaths allows not only to consider the event itself but also its magnitude. This comes at the expense of a possible imprecision of reporting the exact number of deaths caused by a disaster. However, this problem is limited in the sample since all EU countries are industrialised economies with established monitoring authorities and reporting requirements. Additionally, EU countries have an incentive to report disasters since they become eligible to emergency and prevention funding from the EU's Solidarity Fund and the Civil Protection Mechanism.

An instrument also needs to be valid. Thus, the following argues that the instrument complies with the exogeneity restriction for all six indicators.

1. GDP per capita: Since output endogenously determines material productivity, a temporal strategy is pursued, i.e. lagging material productivity by one period compared to GDP per capita. This prevents any simultaneous effect of the instrument on the dependent variable and the endogenous variable. However, this requires natural hazards to lose their effect on GDP after 2 years, which is investigated by estimating the effect of disasters on labour productivity, capital investments, patents, and the labour force. The statistical associations shown in Table 1 indicate that the effect of disasters on these variables lose their effect after 1 year. Thus, a 2-year time lag between the instrument and GDP is sufficiently large to comply with the exclusion restriction.

2. Unemployment: The deaths resulting from disasters are likely to affect the (un)employment rate since firms go out of business, workers pass away or colleagues and family members of victims (temporarily) step out of the workforce. The impact of the instrument on the workforce and labour productivity is considered to test whether there is any statistical association. As Table 1 shows, the impact statistically disappears after 1 year.

3. Wages per capita: Wages could be affected by changes in labour productivity as well as the workforce following a disaster. To justify that the number of deaths do no impact wages other than through material productivity, the effect of disasters on labour productivity and the size of the workforce is tested as both are important factors in determining wages in an economy. As the results below indicate, the instrument remains valid.

4. R\&D per capita: Natural hazards could impact $R \& D$ investments other than through material productivity by affecting patent applications and alternative investments, including capital investments. Patents are typically the result of $\mathrm{R} \& \mathrm{D}$, but it could also capture a shift in priorities of firms once disasters occur, including investing in reconstruction resulting in reduced applications of patents. Table 1 shows that patents and capital investments are statistically insignificantly affected by natural hazards. 


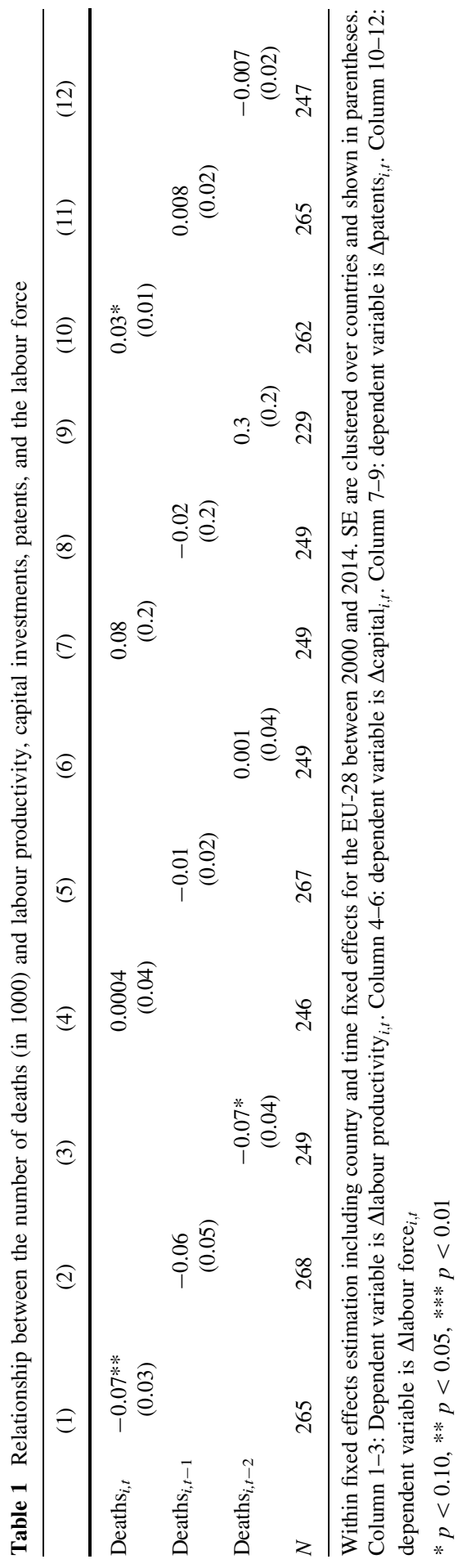


5. Current account: Similar to GDP, the current account (and with it the trade balance) is an integral part of material productivity. This means that a temporal strategy is required, which lags material productivity by one period compared to the current account. Table 1 indicates that the effect of disasters lose their effect on important macroeconomic variables determining the current account (labour productivity and patents) already after 1 year. Therefore, the instrument is lagged twice compared to the current account.

6. GCI: The GCI comprises numerous factors that represent competitiveness, which can be influenced by natural hazards. However, considering the statistical relationships shown in Table 1, the exclusion restriction is likely to hold, in particular because the effect of disasters on patents and capital investments statistically disappears afters 1 year.

In summary, labour productivity (real labour productivity per capita sourced from Eurostat), capital investments (gross capital formation as percentage of GDP from the World Bank), patents (patent applications to the European Patent Office per million inhabitants from Eurostat) and the labour force (the share of the active to total population between 15 and 64 years from Eurostat) are identified as relevant factors that could invalidate the exclusion restriction for the six macroeconomic variables. The following models are estimated:

$$
\Delta y_{i, t}=\kappa_{1} \text { deaths }_{i, t-h}+\varphi_{t}+\theta_{i}+v_{i, t}
$$

where $\varphi_{t}$ are time fixed effects, $\theta_{i}$ are country fixed effects and $h \in(0,1,2) . \Delta y_{i, t}$ is generic since all identified variables mentioned above are used as dependent variables. The results are shown in Table 1.

\subsection{Model specification}

In the main model, it is assumed that any generic competitiveness variable $y_{i, t}$ in the current period is influenced by material productivity in the same period (in $t-1$ for the variables GDP per capita and the current account). This is because productivity changes are likely to have a short-term effect on competitiveness. For instance, wages are negotiated taking current or last year's productivity into account. Thus, the model is formulated as follows:

$$
y_{i, t}=\pi_{1} \frac{\mathrm{GDP}_{i, t}}{\mathrm{DMC}_{i, t}}+\gamma_{t}+\theta_{i}+\varepsilon_{i, t},
$$

where $\frac{\mathrm{GDP}_{i, t}}{\mathrm{DMC}_{i, t}}$ is denoted in Euros (PPP) per kilogramme of material use, $y_{i, t}$ is a generic variable for the six indicators approximating competitiveness, $\gamma_{t}$ are time effects to control for any year-specific events, e.g. the crises that hit the European economies in specific years (e.g. financial, sovereign debt), and $\theta_{i}$ are country fixed effects. Countries are likely to have a different cultural and historic backgrounds, past investment strategies, and other country-specific factors (e.g. economic development, institutional quality). 
The first stage of the model considers the impact of the number of deaths from natural hazards on material productivity. As argued previously, deaths are lagged once (twice for the variables GDP per capita and the current account) to comply with the exogeneity condition. The model is specified as follows:

$$
\frac{\mathrm{GDP}_{i, t}}{\mathrm{DMC}_{i, t}}=\gamma_{1} \text { deaths }_{i, t-1}+\epsilon_{t}+\eta_{i}+\sigma_{i, t},
$$

where $\epsilon_{t}$ are time effects and $\eta_{i}$ are country fixed effects.

The first difference is taken to eliminate trends and other persistent movements in the competitiveness variables and material productivity. The main model is, therefore, specified as follows:

$$
\Delta y_{i, t}=\pi_{1}^{\prime} \Delta \frac{\mathrm{GDP}_{i, t}}{\mathrm{DMC}_{i, t}}+\gamma_{t}^{\prime}+\theta_{i}^{\prime}+\varepsilon_{i, t}^{\prime},
$$

where $\gamma_{t}^{\prime}$ are time effects and $\theta_{i}^{\prime}$ are country fixed effects. The first stage of the model, i.e. Eq. (4), is specified as:

$$
\Delta \frac{\mathrm{GDP}_{i, t}}{\mathrm{DMC}_{i, t}}=\gamma_{1}^{\prime} \text { deaths }_{i, t-1}+\epsilon_{t}^{\prime}+\eta_{i}^{\prime}+\sigma_{i, t}^{\prime},
$$

where the instrument is the number of deaths from disasters, $\epsilon_{t}^{\prime}$ the time and $\eta_{i}^{\prime}$ the country fixed effects. Equations (5) and (6) are estimated using 2SLS with standard errors clustered over countries.

\section{Data description}

\subsection{Competitiveness}

Table 2 describes the six macroeconomic indicators approximating competitiveness.

Table 3 displays descriptive statistics of the six indicators. Generally, there is

\begin{tabular}{|c|c|}
\hline Indicators & Description and data sources \\
\hline GDP per capita & Real GDP in Euro (in PPP) per capita; Eurostat \\
\hline Unemployment & Average unemployment rate in $\%$ of the labour force; Eurostat \\
\hline Wages per capita & $\begin{array}{l}\text { Compensation of employees (wages and salaries plus employer's social } \\
\text { contributions) in PPP per capita; Eurostat }\end{array}$ \\
\hline R\&D per capita & $\begin{array}{l}\text { Total R\&D expenditure in PPP per capita at constant } 2005 \text { prices; } \\
\text { Eurostat }\end{array}$ \\
\hline Current account & Net current account balance with the Rest of the World in 1 billion Euro; Eurostat \\
\hline GCI & Global Competitiveness Index; World Economic Forum \\
\hline
\end{tabular}
great heterogeneity across the sample, in particular GDP per capita, the

Table 2 Description of the indicators approximating competitiveness 
Table 3 Descriptive statistics of the macroeconomic indicators

\begin{tabular}{lllllll}
\hline Indicators & Observations & Mean & Median & Std. deviation & Min & Max \\
\hline GDP per capita $(t-1)$ & 242 & 22,674 & 22,191 & 8,523 & 6,026 & 69,463 \\
Unemployment & 261 & 9.08 & 8.00 & 4.46 & 3.10 & 27.50 \\
Wages per capita & 261 & 10,107 & 9460 & 4607 & 2081 & 34,168 \\
R\&D per capita & 256 & 328 & 262 & 259 & 23.80 & 1050.60 \\
Current account $(t-1)$ & 222 & -0.37 & -3.30 & 40.98 & -105.30 & 206.00 \\
GCI & 261 & 4.67 & 4.51 & 0.49 & 3.77 & 5.65 \\
\hline
\end{tabular}

unemployment rate, wages per capita, $R \& D$ per capita, and the current account. Since the GCI compares countries globally, the EU-28 member states appear to be homogeneous.

Two variables require further elaboration. First, wages per capita is chosen, i.e. wages and salaries plus employers' social contribution. This is equivalent to GDP per capita minus gross operating surplus (excess amount of money of firms after paying for labour input costs), mixed income from capital and labour (selfemployed and family-employed income), and taxes less subsidies on production and imports (EC 2016). Thus, wages per capita is an approximation of the disposable income of each individual for which only incomplete data are available.

Second, the GCI is the arguably the most prominent composite index of competitiveness (Sala-i-Martin and Blanke 2007). ${ }^{7}$ The GCI comprises twelve pillars ranging from institutions and innovations to market efficiency, combining over 110 microeconomic and macroeconomic factors. Despite criticism, it remains a frequently used indicator. ${ }^{8}$ Since the GCI had a methodology break in 2005 , the 2006-2014 trend is extrapolated backwards to the years 2000-2005 to have sufficient observations for the estimations.

\subsection{Material productivity}

The most common way to measure material productivity is taking the ratio between GDP and domestic material consumption (DMC). Data on material productivity in Euro (in PPP) per kilogramme of material are sourced from Eurostat. DMC measures the total amount of materials directly used within an economy. It comprises biomass, metals, minerals, and fossil fuels and is defined as the quantity

\footnotetext{
7 Another composite index is the World Competitiveness Yearbook (IMD WCY 2015), the currently developed Competitiveness Indicator Platform (OECD 2015) and the harmonised price competitiveness indicators (ECB 2016).

8 Thompson (2003) criticises competitiveness indices (and thus the GCI) on four grounds: (1) content validity (methodologies and underlying indicators changes over time), (2) convergent validity (correlation across different indicators is high suggesting that they all measure similar aspects, but not necessarily competitiveness), (3) weighting and nature of variables (weights of indicators are arbitrary), and (4) methodology (the data are not transparently described). Lee (2010) argues that the problem is the lack of theoretical and empirical foundation for using individual sub-indicators. Pérez-Moreno et al. (2015) points to the problem of total substitutability across and within the GCI's twelves pillars, as the index is aggregated using the arithmetic mean.
} 


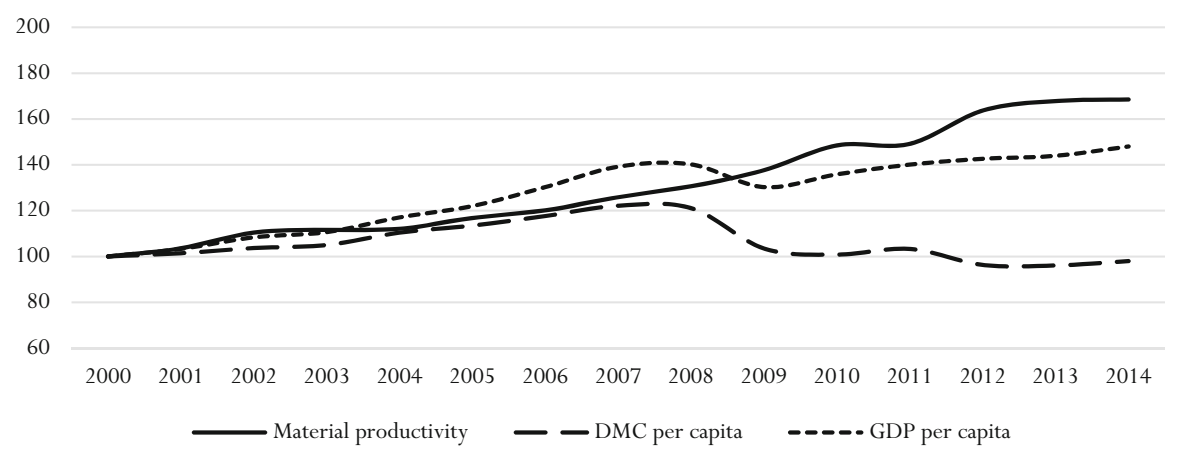

Fig. 1 Trends in GDP per capita, DMC per capita, and material productivity

(in terms of weight) of domestically extracted raw materials, plus direct material imports minus direct material exports (EC 2015b). Despite several shortcomings, DMC is the only material indicator for which data using the same methodology across countries and year are publically accessible. Alternative indicators such as raw material consumption, total material requirements, and material footprint data are only incompletely available (Bringezu and Schütz 2001, 2013).

Figure 1 displays the trends in GDP per capita, DMC per capita and material productivity of the average values of the EU-28 member states across time. Material productivity shows a positive trend, which was temporarily interrupted during 2010-2011 and has levelled out since. GDP per capita increased, except during the financial crisis that has reduced the pre-crisis trend. DMC per capita increased until 2008, followed by a sharp decline in 2009 and has since remained fairly constant. Interestingly, during the financial crisis, material productivity increases because DMC per capita decreased more than GDP per capita.

\subsection{Instrument}

As discussed in Sect. 3, the number of deaths from natural hazards is chosen as an instrument. The data are retrieved from the EM-DAT database, which is maintained by the Center for Research on the Epidemiology of Disasters at the Universite Catholique de Louvain in Belgium. It contains information on more than 18,000 extreme weather events and accidents. Data are collected from UN agencies, nongovernmental organisations, insurance companies, and research institutes. Disasters are included in the database if at least one of the following criteria applies: (1) ten or more people reported killed, (2) hundred or more people reported affected, (3) declaration of a state of emergency, or (4) call for international assistance. All deaths from all types of disasters available in the database are taken, namely droughts, earthquakes, epidemics, extreme temperatures, floods, industrial accidents, landslides, storms, transport accidents, volcanic activity, and wildfires.

Appendix Table 10 shows the number of deaths in all EU-28 member states between 2000 and 2014. It becomes apparent that the heat wave in 2003 has caused an enormous number of victims. Furthermore, the number of deaths varies widely across countries and years. 


\section{Results}

Starting with Eq. (6), Table 4 shows the first stages for all samples of the six indicators. Throughout all samples, the impact of the number of deaths from disasters (in 10,000) has a negative and highly significant impact on material productivity, even though its magnitude is small, i.e. material productivity decreases by around 0.06 Euro/kg per 10,000 deaths. This finding is in line with the literature that suggests a negative impact of disasters on the productive system of an economy (Hochrainer 2009; Raddatz 2009; Hsiang and Jina 2014; DuPont et al. 2015).

Additionally, Table 4 shows that the instrumentation is valid from a statistical perspective. The Kleibergen-Paap $F$ statistics measures the instruments' strength. The rule of thumb is that this F statistic should be above 10 (Angrist and Pischke 2009), which is the case across all samples. The Kleibergen-Paap LM statistic is a test for underidentification, which essentially measures the instrument's relevance. For almost all samples, the null hypothesis that the instrument is underidentified is rejected at the $10 \%$ significance level. All test statistics in the table are robust to heteroscedasticity and arbitrary within correlation (Baum et al. 2007).

The OLS and second stage results are shown in Table 5. Two findings become apparent. First, the material productivity rate has neither a positive nor a negative causal impact on most competitiveness indicators, except a positive effect on the wage rate, with less confidence, on the current account rate. Second, for no competitiveness indicator, OLS and 2SLS are significantly different from zero, which makes it virtually impossible to identify the root of the endogeneity problem. Importantly, considering OLS, one would conclude that the material productivity rate has a negative impact on the GDP rate and a positive effect on the unemployment rate, i.e. increasing unemployment. The statistical significance and of these effects disappear applying the 2SLS approach, suggesting that either

Table 4 First-stage results

\begin{tabular}{|c|c|c|c|c|c|c|}
\hline Sample & $\begin{array}{l}\text { (1) } \\
\text { GDP }\end{array}$ & $\begin{array}{l}\text { (2) } \\
\text { Unemployment }\end{array}$ & $\begin{array}{l}\text { (3) } \\
\text { Wages }\end{array}$ & $\begin{array}{l}\text { (4) } \\
\text { R\&D }\end{array}$ & $\begin{array}{l}(5) \\
\text { Current } \\
\text { account }\end{array}$ & $\begin{array}{l}\text { (6) } \\
\text { GCI }\end{array}$ \\
\hline Deaths $_{i, t-1}$ & & $\begin{array}{c}-0.06^{* * *} \\
(0.02)\end{array}$ & $\begin{array}{c}-0.06 * * * \\
(0.02)\end{array}$ & $\begin{array}{c}-0.06 * * * \\
(0.02)\end{array}$ & & $\begin{array}{c}-0.06 * * * \\
(0.02)\end{array}$ \\
\hline Deaths $_{i, t-2}$ & $\begin{array}{c}-0.06 * * * \\
(0.02)\end{array}$ & & & & $\begin{array}{c}-0.06^{* * * *} \\
(0.02)\end{array}$ & \\
\hline $\begin{array}{l}\text { Kleibergen-Paap } \\
\text { rk Wald } \\
F \text { statistic }\end{array}$ & 12.83 & 14.29 & 14.29 & 11.59 & 10.90 & 14.29 \\
\hline $\begin{array}{l}\text { Kleibergen-Paap } \\
\text { rk LM statistic, } \\
p \text { value }\end{array}$ & 0.098 & 0.094 & 0.094 & 0.105 & 0.108 & 0.094 \\
\hline
\end{tabular}

Dependent variable is $\Delta$ material productivity ${ }_{i, t}$ for columns (2), (3), (4) and (6). Dependent variable is $\Delta$ material productivity ${ }_{i, t-1}$ for columns (1) and (5). Estimated with 2 SLS. Country fixed and time effects are included. SE are clustered over countries and shown in parentheses

$* p<0.10, * * p<0.05, * * * p<0.01$ 


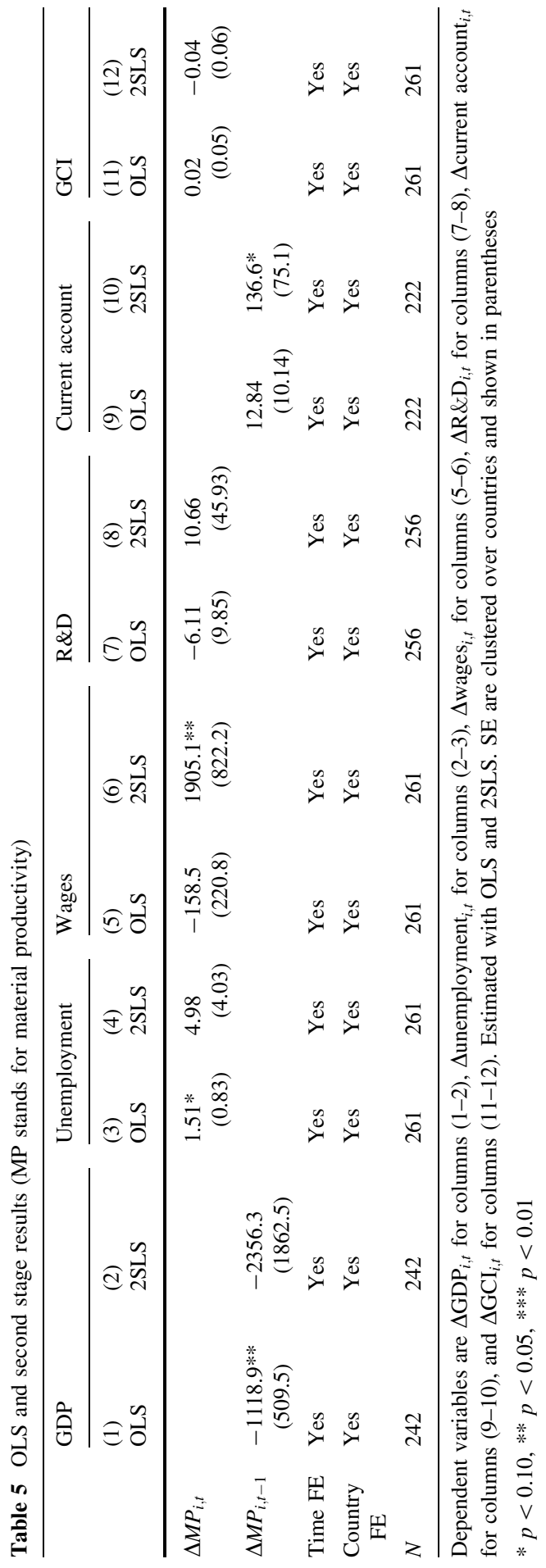


omitted variables, measurement errors or simultaneity (or any combination thereof) have biased these results.

Increasing the material productivity rate by 1 Euro per $\mathrm{kg}$ causes the wage rate per capita to increase by 1905 Euros. This is equivalent to a 0.6 standard deviation increase in wages resulting from a one standard deviation increase in material productivity. The wage increase can be due to the fact that firms pass on parts of their 'material savings' from increased productivity to employees, which in the literature is referred to as the cost channel (Flachenecker 2015). An alternative and complementary explanation would be that unions demand higher wages because of general productivity improvements, thus going beyond labour productivity improvements suggested by standard economic theory.

Increasing the material productivity rate by 1 Euro per $\mathrm{kg}$ causes the current account rate to increase by 137 billion Euros, which is equivalent to a 1.37 standard deviation increase in the current account caused by increasing material productivity by one standard deviation. However, the effect is only significant at the $10 \%$ level. The direction of the effect is in line with previous findings for the trade balance of metals (Dussaux and Glachant 2015). The authors find that increasing material productivity through domestic recycling substitutes the import of primary metals, hence ceteris paribus increasing the current account. Similar claims are brought forward in the field of energy efficiency (UNIDO 2011). Nevertheless, the result should merely be seen as an indication of a positive impact of the material productivity rate on the current account rate.

\subsection{Robustness checks}

Since the only statistically significant effects are on the wage rate and the current account rate, robustness checks are limited to those variables. Excluding individual countries does not change the conclusions drawn from Table 5. Excluding the country fixed effects does not substantially change the results. Excluding any potential outliers does not change the results significantly. The time effects are jointly statistically different from zero and thus included in the estimations. The results are tested regarding different standard errors (i.e. robust to heterogeneity and homogeneity), concluding that the results remain unchanged.

Table 6 shows the results for the wage rate and the current account rate when excluding the years of the financial crisis (2008-2010) and dividing the samples into the EU-15 and non-EU-15 countries. In essence, the results are unchanged, with the exception that the effect on the current account is just outside the $10 \%$ significance level when the years of the financial crisis are excluded. This could be the results of the instrument reducing its strength.

Moreover, several variables are controlled for that potentially have an impact on wages. According to standard economic theory, labour productivity is an essential determinant of wages (e.g. Millea 2002). Data on real labour productivity per capita are sourced from Eurostat. R\&D expenditures can impact wages negatively by reducing available funds as well as positively through possible rents from R\&D (e.g. Lokshin and Mohnen 2013). Data on R\&D expenditures in PPP per capita at constant 2005 prices are taken from Eurostat. 
Table 6 Robustness checks by excluding the financial crisis and the new member states

\begin{tabular}{|c|c|c|c|c|}
\hline & Wages & $\begin{array}{l}\text { Current } \\
\text { account }\end{array}$ & Wages & $\begin{array}{l}\text { Current } \\
\text { account }\end{array}$ \\
\hline & \multicolumn{2}{|c|}{ Excl. 2008-2010 } & \multicolumn{2}{|l|}{ EU-15 } \\
\hline & (1) & (2) & (3) & (4) \\
\hline$\Delta$ material productivity $_{i, t}$ & $\begin{array}{r}1761.47 * * \\
(836.03)\end{array}$ & & $\begin{array}{l}2301.57 * * \\
\quad(1039.31)\end{array}$ & \\
\hline$\Delta$ material productivity $_{i, t-1}$ & & $\begin{array}{l}128.77 \\
(83.14)\end{array}$ & & $\begin{array}{r}104.98 * \\
(55.83)\end{array}$ \\
\hline $\begin{array}{l}\text { Kleibergen-Paap rk Wald } \\
F \text { statistic }\end{array}$ & 11.32 & 7.68 & 17.21 & 14.85 \\
\hline $\begin{array}{l}\text { Kleibergen-Paap rk LM statistic, } \\
\quad p \text { value }\end{array}$ & 0.101 & 0.125 & 0.072 & 0.077 \\
\hline$N$ & 209 & 170 & 147 & 126 \\
\hline
\end{tabular}

Columns (1) and (3): dependent variable is $\Delta$ wages $_{i, t}$. Columns (2) and (4): dependent variable is $\Delta$ current account $t_{i, t}$. Estimated with 2 SLS, including country fixed and time effects. SE clustered over countries are shown in parentheses

$* p<0.10, * * p<0.05, * * * p<0.01$

The labour force is one factor in determining the supply of labour and thus wages (e.g. Heckman 1974). Eurostat data are considered, which defines the labour force as the share of the active to total population between 15 and 64 years. In addition, capital investments are argued to impact on wages, not at least due to the substitutability between capital and labour (e.g. Holm et al. 1994; Rowthorn 1999). Data on gross capital formation as percentage of GDP are taken from the World Bank. As shown in Table 7, the results are unchanged and fairly robust to these control variables.

Control variables are also included for the current account model. The literature argues that foreign direct investments (FDIs) can increase the current account by increasing national savings (e.g. Fry 1996). Data on net inflows of FDI in current USD are taken from the World Bank. The literature further finds that investments, including in R\&D, can improve the current account (e.g. Glick and Rogoff 1995). R\&D expenditure data in PPP per capita at constant 2005 prices are retrieved from Eurostat. Similarly, the general competitiveness of a country, and patents (e.g. Crosby 2000) have an effect on the current and are thus controlled for. Data on the GCI are taken from the WEF and patent applications to the European Patent Office per million inhabitants are taken from Eurostat. As shown in Table 8, the results remain robust.

Besides experimenting with different standard errors as mentioned above, it is important to also control for serial correlation using the approach suggested by Newey and West (1987). Equation (5) is thus estimated controlling for various autocorrelation structures. Table 9 shows that the results are essentially unchanged when using $\mathrm{AR}(1), \operatorname{AR}(2)$ and $\operatorname{AR}(3)$ error structures.

Individual years are also excluded, which does not change the results, except for the year 2003. This may not come as a surprise since Appendix Table 10 shows that 
Table 7 Checking the robustness of the results for wages by including control variables

\begin{tabular}{|c|c|c|c|c|}
\hline & \multicolumn{4}{|l|}{ Wages } \\
\hline & (1) & (2) & (3) & (4) \\
\hline$\Delta$ material productivity $_{i, t}$ & $\begin{array}{r}1706.15 * * \\
(807.01)\end{array}$ & $\begin{array}{r}1723.78 * * \\
(801.33)\end{array}$ & $\begin{array}{r}2064.18 * * \\
(835.83)\end{array}$ & $\begin{array}{r}1791.25 * * \\
(789.25)\end{array}$ \\
\hline$\Delta$ labour productivity $_{i, t}$ & $\begin{array}{l}17.73 \\
(22.04)\end{array}$ & & & \\
\hline$\Delta \mathrm{R} \& \mathrm{D}_{i, t}$ & & $\begin{array}{r}6.14 * * * \\
(1.95)\end{array}$ & & \\
\hline$\Delta$ labour force ${ }_{i, t}$ & & & $\begin{array}{l}68.85^{*} \\
\quad(40.04)\end{array}$ & \\
\hline$\Delta$ capital $_{i, t}$ & & & & $\begin{array}{l}52.23 * * \\
(22.49)\end{array}$ \\
\hline $\begin{array}{l}\text { Kleibergen-Paap rk Wald } \\
F \text { statistic }\end{array}$ & 11.15 & 11.78 & 13.04 & 14.50 \\
\hline $\begin{array}{l}\text { Kleibergen-Paap rk LM } \\
\text { statistic, } p \text { value }\end{array}$ & 0.103 & 0.103 & 0.096 & 0.091 \\
\hline$N$ & 261 & 256 & 260 & 260 \\
\hline
\end{tabular}

Dependent variable is $\Delta$ wages $_{i, t}$. Estimated with 2SLS, including country fixed and time effects. SE clustered over countries are shown in parentheses

$* p<0.10, * * p<0.05, * * * p<0.01$

Table 8 Checking the robustness of the results for the current account by including control variables

\begin{tabular}{|c|c|c|c|c|}
\hline & \multicolumn{4}{|l|}{ Current account } \\
\hline & (1) & (2) & (3) & (4) \\
\hline$\Delta$ material productivity $_{i, t-1}$ & $149.12 *(85.46)$ & $\begin{array}{r}111.55^{*} \\
(62.01)\end{array}$ & $\begin{array}{l}136.70 * \\
(75.31)\end{array}$ & $\begin{array}{r}147.37 * \\
(84.77)\end{array}$ \\
\hline$\Delta \mathrm{FDI}_{i, t}$ & $\begin{array}{r}-4.36^{-11} \\
\left(2.76^{-11}\right)\end{array}$ & & & \\
\hline$\Delta \mathrm{R} \& \mathrm{D}_{i, t}$ & & $\begin{array}{l}0.1501 * * \\
\quad(0.0726)\end{array}$ & & \\
\hline$\Delta \mathrm{GCI}_{i, t}$ & & & $\begin{array}{l}11.85 \\
(27.64)\end{array}$ & \\
\hline$\Delta$ patents $_{i, t}$ & & & & $\begin{array}{l}0.2389 \\
(0.1619)\end{array}$ \\
\hline $\begin{array}{l}\text { Kleibergen-Paap rk Wald } \\
F \text { statistic }\end{array}$ & 9.18 & 14.59 & 10.73 & 9.26 \\
\hline $\begin{array}{l}\text { Kleibergen-Paap rk LM } \\
\text { statistic, } p \text { value }\end{array}$ & 0.117 & 0.087 & 0.108 & 0.120 \\
\hline$N$ & 221 & 220 & 222 & 222 \\
\hline
\end{tabular}

Dependent variable is $\Delta$ current account ${ }_{i, t}$. Estimated with 2 SLS, including country fixed and time effects. SE clustered over countries are shown in parentheses

$* p<0.10, * * p<0.05, * * * p<0.01$

the heatwave in 2003 caused a substantial amount of deaths. For this analysis, this means that the effect of the 2003 heatwave constitutes an important event in explaining the variation in material productivity. However, the effects of this 
Table 9 Controlling for autocorrelation error structures

\begin{tabular}{|c|c|c|c|c|c|c|}
\hline & \multicolumn{3}{|l|}{ Wages } & \multicolumn{3}{|c|}{ Current account } \\
\hline & AR (1) & AR (2) & AR (3) & AR (1) & AR (2) & AR (3) \\
\hline$\Delta M P_{i, t}$ & $\begin{array}{l}1905.05 * \\
(1061.77)\end{array}$ & $\begin{array}{l}1905.05 * \\
(1063.55)\end{array}$ & $\begin{array}{l}1905.05 * \\
(1046.80)\end{array}$ & & & \\
\hline$\Delta M P_{i, t-1}$ & & & & $\begin{array}{r}136.56^{*} \\
(81.25)\end{array}$ & $\begin{array}{r}136.56^{*} \\
(79.74)\end{array}$ & $\begin{array}{r}136.56 * \\
(82.33)\end{array}$ \\
\hline$N$ & 261 & 261 & 261 & 222 & 222 & 222 \\
\hline
\end{tabular}

Dependent variable are $\Delta$ wages $_{i, t}$ and $\Delta$ current account $_{i, t} .2$ SLS estimation with country fixed and time effects. Newey-West SE are shown in parentheses

$* p<0.10, * * p<0.05, * * * p<0.01$

heatwave would have been likely to be similar in other countries, across time and under different severities (counterfactual). Despite previous heatwaves and other disasters, EU countries still seem unprepared for the substantial impacts and magnitude of such events on human lives and economic activity (García-Herrera et al. 2010). The effect's similarity across economies is particularly likely since the EU is a relatively homogenous group of industrialised countries. Shutting down nuclear power plants is one example, which is required every time when extreme temperatures or low river levels occur, which is independent from when or where such events take place (de Bono 2004). Thus, the economic rationale behind the results remains valid.

\section{Discussion}

The results provide evidence that increasing the material productivity rate leaves four out of six macroeconomic indicators approximating competitiveness statistically unchanged. From a policy perspective, this means that claiming increasing material productivity improves macroeconomic competitiveness in the EU might be misleading. However, there is no evidence that competitiveness is harmed as a result of increases in material productivity. Thus, these results can be interpreted as a statement of caution. It has to be noted that the analysis critically depends on the indicators considered to approximate macroeconomic competitiveness. The measures chosen in this analysis are the result of reviewing the literature, thus going beyond the current empirical literature that fails to clarify the concept. Nevertheless, the set of indicators used in this analysis needs to be tested against a different set of indicators. ${ }^{9}$

\footnotetext{
9 The analysis has also been tested using the following indicators as dependent variables: exports per capita, exports of high-technology goods and services per capita, carbon dioxide emissions per capita, a price competitiveness and institutional competitiveness measure from the European Central Bank, patent application per capita, foreign direct investments, and labour productivity. The results confirm the conclusions drawn from this analysis.
} 


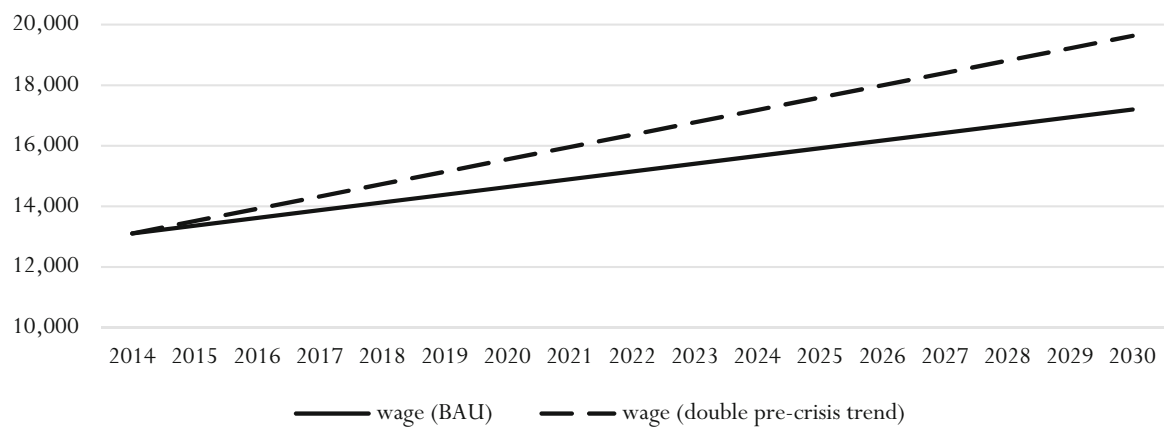

Fig. 2 Extrapolated future average wage per capita developments of the business-as-usual (BAU) trend compared to doubling the pre-crisis material productivity trend

The results provide evidence for a statistically significant causal impact of increasing the material productivity rate on the wages rate per capita across the EU28 member states. The meaningfulness of the result's magnitude can be exemplified by extrapolating it into the future. If the EU were to double its material productivity rate compared to its pre-crisis trend (i.e. 2000-2007) until 2030, as suggested by the European Resource Efficiency Platform (2014), the wage increase beyond its trend from doubling the material productivity rate would be 2431 Euros for every EUcitizen in 2030 or 152 Euro per year. This is equivalent to approximately 1.2 trillion Euros gross gain in wages from doubling the pre-crisis trend in material productivity. Figure 2 illustrates the change in wages per capita by doubling the pre-crisis trend.

Generally, the findings of this analysis have three implications. First, those scholars arguing that relatively high wages are detrimental for the competitiveness of countries (e.g. Siggel 2006; Acemoglu et al. 2016) would interpret this finding as being a setback to competitiveness. However, those scholars arguing that competitiveness is about increasing welfare (e.g. Aiginger 2006; Snowdon and Stonehouse 2006; Salvatore 2010) could see this result as improving competitiveness. Thus, there is no consensus whether wage increases are positive or negative for macroeconomic competitive.

Second, wage increases are likely to increase the rebound effect and thus environmental pressures. This has repercussions on the calculation of the rebound effect itself, for instance, the model used by Meyer (2011) assumes that gains from material productivity, i.e. 'material savings', are re-invested into innovation activity, which reduces the magnitude of the rebound effect. This finding suggests that at least part of the gains is passed on to employees.

Third, employees are benefiting from increases in material productivity in addition to increases in labour productivity (Table 7). It seems that employees benefit generally from productivity rather than the pure increase in labour productivity.

The results also indicate that increasing the material productivity rate increases the current account rate. Two mechanisms are consistent with this result. First, increased productivity leads to an increase in exports, because more productive 
firms self-select themselves into international markets (Kunst and Marin 1989; Wagner 2007). Second, given that the EU imports approximately three times more materials than it exports, imports are likely to increase less (or decrease more) compared to exports once material productivity increases. In both scenarios, the current account ceteris paribus increases.

Policy making could focus on how the gains from material productivity are being channelled. If the gains are passed on to employees, they are likely to increase the rebound effect, undermining efforts to reduce absolute material consumption. At the same time, material productivity policies could be justified as a social policy rather than one improving competitiveness. This would require further analyses on the distributional effects of material productivity increases. However, channelling the gains into eco-innovations through incentives (e.g. tax breaks, financial support) could further improve firms' productivity and create spill-over effects while reducing the rebound effect and associated environmental pressures. Channelling gains from productivity measures into eco-innovation is acknowledged as one strategy to reduce the rebound effect (Font Vivanco et al. 2016). Even though ecoinnovations themselves are associated with additional rebound effects (Font Vivanco et al. 2015), the effect is likely to be lower each time gains are reinvested, hence reducing associated environmental pressures, at least in relative terms.

\section{Conclusion}

This paper investigates the causal impact of material productivity on competitiveness in the European Union (EU). The current literature, dominated by interdisciplinary scholars and policy circles, claims that increasing material productivity improves macroeconomic competitiveness. However, two limitations of the literature can be identified. First, it fails to clarify the concept and measurement of competitiveness on the macroeconomic level. Second, it lacks to take the endogeneity of material productivity in empirical studies into account.

This paper attempts to address the two shortcomings by (1) reviewing the concept of macroeconomic competitiveness and identifying six conventional macroeconomic indicators to approximate competitiveness, and (2) using a panel data set for the 28 member states of the EU between 2000 and 2014 to estimate the causal impact of material productivity on each of the six indicators. The number of deaths from natural hazards is taken as an instrument, which is shown to be both relevant and valid. The results suggest that increasing the material productivity rate has no causal impact on most indicators, with the exceptions of positive and causal impacts on the wage rate per capita and, with lower confidence, on the current account.

The results indicate that claiming increases in material productivity improves macroeconomic competitiveness might not be justified. While it is debateable whether higher wages improve or harm competitiveness, overall, there is no evidence that increasing material productivity is a setback to competitiveness, while 
acknowledging that there is no optimal set of indicators approximating competitiveness.

Channelling the gains from material productivity could be the focus of policy making since increased wages are likely to result in a more pronounced rebound effect and thus environmental pressures. Thus, through incentives, including tax breaks and financial support, policy makers could redirect gains into ecoinnovations, which helps to further improve productivity and make the absolute reduction of material use and reduction of associated environmental pressures become more likely. Further investigations are necessary, in particular testing these results against different sets of indicators on the macroeconomic level as well as analyses on the microeconomic level, to shed light into the economy-wide effects of moving towards material productive economies.

Acknowledgements The author would like to thank Raimund Bleischwitz, Paolo Agnolucci, Magnus Söderberg, Jun Rentschler, Shunsuke Managi, and three anonymous reviewers for very useful comments and suggestions. All remaining errors are those of the author.

Open Access This article is distributed under the terms of the Creative Commons Attribution 4.0 International License (http://creativecommons.org/licenses/by/4.0/), which permits unrestricted use, distribution, and reproduction in any medium, provided you give appropriate credit to the original author(s) and the source, provide a link to the Creative Commons license, and indicate if changes were made.

\section{Appendix}

See Table 10. 


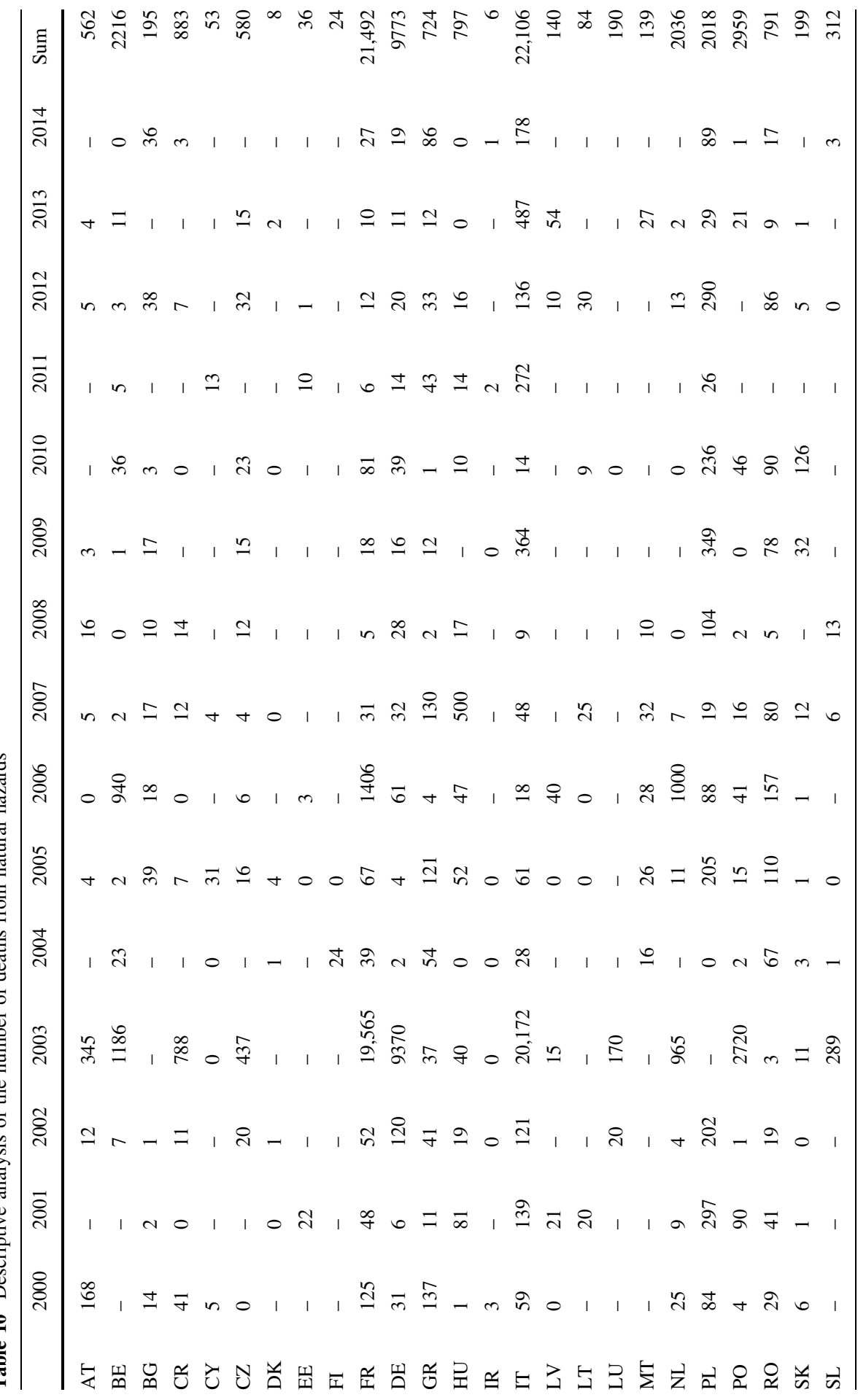

\section{Springer}




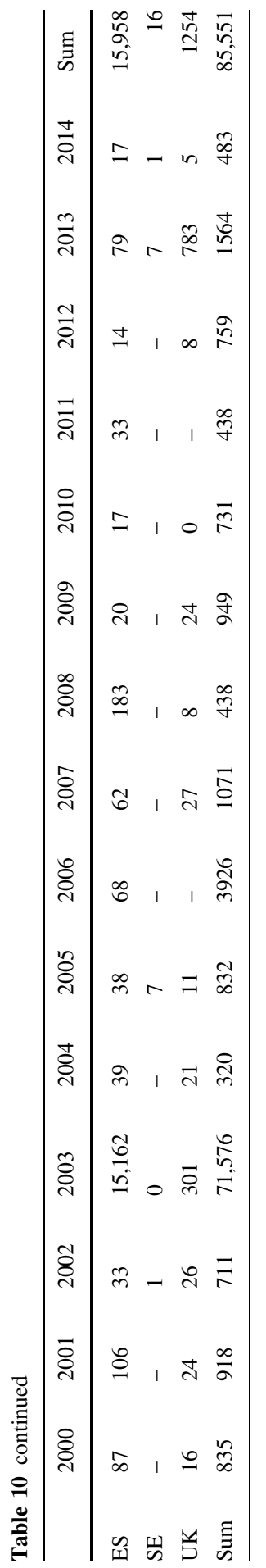




\section{References}

Acemoglu D, Autor D, Dorn D et al (2016) Import Competition and the Great U.S. Employment Sag of the 2000s. J Labor Econ 34:S141-S198. doi:10.3386/w20395

Aiginger K (2006) Competitiveness: from a dangerous obsession to a welfare creating ability with positive externalities. J Ind Compet Trade 6:161-177. doi:10.1007/s10842-006-9475-6

Aiginger K, Vogel J (2015) Competitiveness: from a misleading concept to a strategy supporting Beyond GDP goals. Compet Rev 25:497-523. doi:10.1108/CR-06-2015-0052

Allwood JM, Ashby MF, Gutowski TG, Worrell E (2011) Material efficiency: a white paper. Resour Conserv Recycl 55:362-381. doi:10.1016/j.resconrec.2010.11.002

AMEC, Bio IS (2013) The opportunities to business of improving resource efficiency. Cheshire

Angrist JD, Krueger AB (2001) Instrumental variables and the search for identification: from supply and demand to natural experiments. J Econ Perspect 15:69-85. doi:10.1257/jep.15.4.69

Angrist JD, Pischke J-S (2009) Mostly harmless econometrics: an empiricist's companion. Princeton University Press, Princeton, USA

Askenazy P (2003) Minimum wage, exports and growth. Eur Econ Rev 47:147-164. doi:10.1016/S00142921(02)00187-3

Bahn-Walkowiak B, Steger S (2015) Resource targets in Europe and worldwide: an overview. Resources 4:597-620. doi:10.3390/resources4030597

Bassi AM, Tan Z, Mbi A (2012) Estimating the impact of investing in a resource efficient, resilient global energy-intensive manufacturing industry. Technol Forecast Soc Change 79:69-84. doi:10.1016/j. techfore.2011.05.011

Baum CF, Schaffer ME, Stillman S (2007) Enhanced routines for instrumental variables/generalized method of moments estimation and testing. Stata J 7:465-506

Bleischwitz R (2003) Cognitive and institutional perspectives of eco-efficiency. Ecol Econ 46:453-467. doi:10.1016/S0921-8009(03)00186-1

Bleischwitz R (2005) Gemeinschaftsgüter durch Wissen generierende Institutionen. Ein evolutorischer Ansatz für die Wirtschaftspolitik. Metropolis-Verlag

Bleischwitz R (2010) International economics of resource productivity-relevance, measurement, empirical trends, innovation, resource policies. Int Econ Econ Policy 7:227-244. doi:10.1007/ s10368-010-0170-z

Bleischwitz R (2012) Towards a resource policy-unleashing productivity dynamics and balancing international distortions. Miner Econ 24:135-144

Bleischwitz R, Steger S (2009) Decoupling GDP from resource use, resource productivity and competitiveness: a cross-country comparison, Sustain. growth resour. product. econ. glob. policy issues. Greenleaf Publishing, Sheffield, pp 172-193

Bleischwitz R, Bahn-Walkowiak B, Onischka M et al (2007) The relation between resource productivity and competitiveness. Project ENV.G.1/ETU/2007/0041. Wuppertal Institute, Wuppertal, Germany

Bleischwitz R, Steger S, Onischka M, Bahn-Walkowiak B (2009) Potenziale der Materialeffizienz erschließen. Ökologisches Wirtschaften, pp 35-39

Bringezu S, Schütz H (2001) Total material requirement of the European Union. Technical report No 55. Wuppertal Institute, Wuppertal, Germany

Bringezu S, Schütz H (2013) Economy-wide indicators. Material Flow Analysis. Wuppertal, Germany

Bringezu S, Schütz H, Steger S, Baudisch J (2004) International comparison of resource use and its relation to economic growth. Ecol Econ 51:97-124. doi:10.1016/j.ecolecon.2004.04.010

Bruyn S, Markowska A, de Jong F, Blom M (2009) Resource productivity, competitiveness and environment policies, Delft

Budzinski O (2007) Competition and responsible corporate governance. In: Bleischwitz R (ed) Corp. Gov. sustain. a co-evolutionary view resour. manag. Edward Elgar, Cheltenham/Bookham, pp 26-47

Cahuc P, Michel P (1996) Minimum wage unemployment and growth. Eur Econ Rev 40:1463-1482. doi:10.1016/0014-2921(95)00035-6

Caplin A, Nalebuff B (1997) Competition among institutions. J Econ Theory 72:306-342. doi:10.1006/ jeth. 1996.2212

Cavallo E, Powell A, Becerra O (2010) Estimating the direct economic damages of the earthquake in Haiti. Econ J 120:298-312. doi:10.1111/j.1468-0297.2010.02378.x 
Cavallo E, Galiani S, Noy I, Pantano J (2013) Catastrophic natural disasters and economic growth. Rev Econ Stat 95:1549-1561. doi:10.1162/REST_a_00413

Ciais P, Reichstein M, Viovy N et al (2005) Europe-wide reduction in primary productivity caused by the heat and drought in 2003. Nature 437:529-533. doi:10.1038/nature03972

Coase R (1998) The new institutional economics. Am Econ Rev 88:72-74

Cooper S, Skelton ACH, Owen A et al (2016) A multi-method approach for analysing the potential employment impacts of material efficiency. Resour Conserv Recycl 109:54-66. doi:10.1016/j. resconrec.2015.11.014

Crosby M (2000) Patents, innovation and growth. Econ Rec 76:255-262

Dahlstrom K, Ekins P (2005) Eco-efficiency trends in the UK steel and aluminum industries and resource productivity. J Ind Ecol 9:171-188

de Bono A (2004) Impacts of summer 2003 heat wave in Europe. Nairobi, Kenya

de Soto H (2003) The mystery of capital: why capitalism triumphs in the West and fails everywhere else. Basic Books

Dechezleprêtre A, Sato M (2014) The impacts of environmental regulations on competitiveness. Grantham Researc Inst Clim Chang Environ Glob Green Growth Inst. doi:10.1086/342808

Distelkamp M, Meyer B, Meyer M (2010) Quantitative und qualitative Analyse der ökonomischen Effekte einer forcierten Ressourceneffizienzstrategie Abschlussbericht zu AP5

DuPont W, Noy I, Okuyama Y, Sawada Y (2015) The long-run socio-economic consequences of a large disaster: the 1995 earthquake in Kobe. PLoS ONE 10:1-17. doi:10.1371/journal.pone.0138714

Dussaux D, Glachant M (2015) How much does recycling reduce imports? Evidence from metallic raw materials (working paper), Paris

EBRD (2015) Green economy transition approach, London

EC (2008) The raw materials initiative-meeting our critical needs for growth and jobs in Europe $\operatorname{COM}(2008) 699$ final. Commun from Com to Eur Parliam Councel 13

EC (2011) Roadmap to a resource efficient Europe-COM(2011) 571 final, Brussels

EC (2014a) An investment plan for Europe-COM(2014) 903 final, pp 1-20

EC (2014b) European Competitiveness Report 2014, Brussels

EC (2014c) Study on modelling of the economic and environmental impacts of raw material consumption, Brussels

EC (2015a) Closing the loop—an EU action plan for the circular economy. doi:10.1017/ CBO9781107415324.004

EC (2015b) Domestic material consumption-explanatory text, Luxembourg

EC (2016) Annual national accounts (nama10), Luxembourg

ECB (2016) Harmonised competitiveness indicators, Frankfurt

Eco-Innovation Observatory (2012) Closing the eco-innovation gap-an economic opportunity for business, Brussels

Ecorys (2011) Study on the competitiveness of the European companies and resource efficiency, Rotterdam

EEA (2011) Resource efficiency in Europe_policies and approaches in 31 EEA member and cooperating countries, Copenhagen

European Resource Efficiency Platform (2014) Manifesto and policy recommendations, Brussels

Fagerberg J, Srholec M, Knell M (2007) The competitiveness of nations: why some countries prosper while others fall behind. World Dev 35:1595-1620. doi:10.1016/j.worlddev.2007.01.004

Felbermayr G, Gröschl J (2013) Natural disasters and the effect of trade on income: a new panel IV approach. Eur Econ Rev 58:18-30. doi:10.1016/j.euroecorev.2012.11.008

Fh-ISI, Wuppertal Institute, Arthur D. Little GmbH (2005) Studie zur Konzeption eines Programms für die Steigerung der Materialeffizienz in mittelständischen Unternehmen. Wiesbaden

Flachenecker F (2015) Sustainability, resource efficiency and competitiveness an assessment of resource efficiency policies in the European Union. Bruges Eur Econ Res Pap 32:1-33

Font Vivanco D, Kemp R, van der Voet E (2015) The relativity of eco-innovation: environmental rebound effects from past transport innovations in Europe. J Clean Prod 101:71-85. doi:10.1016/j. jclepro.2015.04.019

Font Vivanco D, Kemp R, van der Voet E (2016) How to deal with the rebound effect? A policy-oriented approach. Energy Policy 94:114-125. doi:10.1016/j.enpol.2016.03.054

Fry MJ (1996) How foreign direct investment in Pacific Asia improves the current account. J Asian Econ 7:459-486. doi:10.1016/S1049-0078(96)90021-4

G7 (2015) Leaders'Declaration G7 Summit 7-8 June 2015, Schloss Elmau 
G7 (2016) Communiqué G7 Toyama environment ministers' meeting in Toyama, Japan. Toyama

García-Herrera R, Díaz J, Trigo RM et al (2010) A review of the European summer heat wave of 2003. Crit Rev Environ Sci Technol 40:267-306. doi:10.1080/10643380802238137

Glick R, Rogoff K (1995) Global versus country-specific productivity shocks and the current account. J Monet Econ 35:159-192

Graedel TE, Barr R, Chandler C et al (2012) Methodology of metal criticality determination. Environ Sci Technol 46:1063-1070. doi:10.1021/es203534z

Heckman JJ (1974) Shadow prices, market wages, and labor supply. Econometrica 42:679-694. doi:10. 2307/1913937

Hinterberger F, Giljum S, Hammer M (2003) Material flow accounting and analysis (MFA)—a valuable tool for analyses of society-nature interrelationships. SERI Background Paper, Vienna, Austria

Hochrainer S (2009) Assessing the macroeconomic impact of natural disasters: are there any? World Bank Policy Res Work Pap 4968:1-43

Holm P, Honkapohja S, Koskela E (1994) A monopoly-union model of wage determination with capital and taxes. An empirical application to the Finnish manufacturing. Eur Econ Rev 38:285-303. doi:10.1016/0014-2921(94)90059-0

Hsiang SM, Jina AS (2014) The causal effect of environmental catastrophe on long-run economic growth: evidence from 6,700 cyclones. Natl Bur Econ Res Work Pap Ser. doi:10.3386/w20352

IMD WCY (2015) Methodology and principles of analysis. IMD world comeptitiveness yearbook 2015. Lusanne, Switzerland

Jackson O (2014) Natural disasters, foreign aid, and economic growth. doi:10.2139/ssrn.2329404

Kagawa S, Hashimoto S, Managi S (2014) Special issue: studies on industrial ecology. Environ Econ Policy Stud 17:361-368. doi:10.1007/s10018-014-0090-1

Kahn EM (2005) The death toll from natural disasters: the role of income, geography, and institutions. Rev Econ Stat 87:271-284

Kaldor N (1978) The effect of devaluations on trade in manufactures. Furth Essays Appl Econ, pp 99-118

Kraay A (2012) Instrumental variables regressions with uncertain exclusions restrictions: a Bayesian approach. J Appl Econ 27:108-128. doi:10.1002/jae.1148

Krugman P (1994) Competiveness a dangerous obsession. Foreign Aff 73:28-44

Krugman PR (1996) Making sense of the competitiveness debate. Oxford Rev Econ Policy 12:17-25. doi:10.1093/oxrep/12.3.17

Kunst RM, Marin D (1989) On exports and productivity: a causal analysis. Rev Econ Stat 71:699-703

Lall S (2001) Comparing National competitive performance: an economic analysis of world economic forum competitiveness index. QEH Working Paper-QEHWPS61, 1-41

Lee C (2010) An institutional perspective of national competitiveness. Singapore Econ Rev 55:671-683. doi: $10.1142 / \mathrm{S} 0217590810004000$

Lehner F, Bierter W, Charles T (1999) Resource productivity, competitiveness, and employment in the advanced economies. Factor 10:105-133

Lokshin B, Mohnen P (2013) Do R\&D tax incentives lead to higher wages for R\&D workers? Evidence from the Netherlands. Res Policy 42:823-830. doi:10.1016/j.respol.2012.12.004

McKinsey Global Institute (2011) Resource Revolution: Meeting the world's energy, materials, food, and water needs, New York

Meadows D, Goldsmith E, Meadow P (1972) The limits to growth-a report to the club of Rome. Universe Books, New York

Meyer B (2011) Macroeconomic modelling of sustainable development and the links between the economy and the environment - a report prepared for the European Commission. DG Environment, Osnabruck

Meyer B, Meyer M, Distelkamp M (2011) Modeling green growth and resource efficiency: new results. Miner Econ 24:145-154. doi:10.1007/s13563-011-0008-3

Millea M (2002) Disentangling the wage-productivity relationship: evidence from select OECD member countries. Int Adv Econ Resour 8:314-323

Nakano M, Managi S (2012) Waste generations and efficiency measures in Japan. Environ Econ Policy Stud 14:327-339. doi:10.1007/s10018-012-0038-2

Newey W, West K (1987) A simple, positive semi-definite, heteroscedasticity and autocorrelation consistent covariance matrix. Econometrica 55:703-708

North D (1990) Institutions, institutional change, and economic performance. In: Douglas M (ed) How institutions think. Syracuse University Press, Syracuse, NY, USA, pp 45-128

North DC (1991) Institutions. J Econ Perspect 5:97-112. doi:10.1257/jep.5.1.97 
Noy I, DuPont W (2016) The long-term consequences of natural disasters-a summary of the literature, Wellington

Oakdene Hollins (2011) The further benefits of business resource efficiency. A research report completed for the Department for Environment, Food and Rural Affairs, London

OECD (2007) Measuring material flows and resource productivity, vol I. The OECD Guide, Paris

OECD (2011) Resource productivity in the G8 and the OECD. A report in the framework of the Kobe 3R action plan

OECD (2015) Development of OECD competitiveness indicators platform, Paris

OECD (2016) Policy guidance on resource efficiency. OECD Publishing. doi:10.1787/9789264257344-en

Panizza U, Presbitero AF (2014) Public debt and economic growth: is there a causal effect? J Macroecon 41:21-41. doi:10.1016/j.jmacro.2014.03.009

Pérez-Moreno S, Rodríguez B, Luque M (2015) Assessing global competitiveness under multi-criteria perspective. Econ Model 53:398-408. doi:10.1016/j.econmod.2015.10.030

Porter M (1990) The competitive advantage of nations. Harv Bus Rev, pp 1-18

Raddatz C (2009) The wrath of God macroeconomic costs of natural disasters. World bank policy research working paper 5039. Washington, DC, USA

Ramsay KW (2011) Revisiting the resource curse: natural disasters, the price of oil, and democracy. Int Organ 65:507-529. doi:10.1017/S002081831100018X

Reed WR (2015) On the practice of lagging variables to avoid simultaneity. Oxf Bull Econ Stat 77:897-905. doi:10.1111/obes.12088

Reinert ES (1995) Competitiveness and its predecessors-a 500-year cross-national perspective. Struct Chang Econ 6:23-42

Robine JM, Cheung SLK, Le Roy S et al (2008) Death toll exceeded 70,000 in Europe during the summer of 2003. Comptes Rendus Biol 331:171-178. doi:10.1016/j.crvi.2007.12.001

Rockström J, Steffen W, Noone K et al (2009) A safe operating space for humanity. Nature. doi:10.1038/ $461472 \mathrm{a}$

Rowthorn R (1999) Unemployment, wage bargaining and capital-labour substitution. Camb J Econ 23:413-425. doi:10.1093/cje/23.4.413

Rozmahel P, Grochová LI, Litzman M (2014) Evaluation of competitiveness in the European Union: alternative perspectives. Proc Econ Financ 12:575-581. doi:10.1016/S2212-5671(14)00381-5

Sakamoto T, Managi S (2017) New evidence of environmental efficiency on the export performance. Appl Energy 185:615-626. doi:10.1016/j.apenergy.2016.10.126

Sala-i-Martin X, Blanke J (2007) The global competitiveness index: measuring the productive potential of Nations. Glob Compet Index, World Econ Forum 3-81

Salvatore D (2010) Globalisation, international competitiveness and growth: advanced and emerging markets, large and small countries. J Int Commer Econ Policy 1:21-32. doi:10.1142/ S179399331000007X

Schröter M, Lerch C, Jäger A (2011) Materialeffizienz in der Produktion: Einsparpotenziale und Verbreitung von Konzepten zur Materialeinsparung im Verarbeitenden Gewerbe. A report prepared for the German Federal Ministry of the Economy and Technology, Karlsruhe

Siggel E (2006) International competitiveness and comparative advantage: a survey and a proposal for measurement. J Ind Compet Trade 6:137-159. doi:10.1007/s10842-006-8430-X

Snowdon B, Stonehouse G (2006) Competitiveness in a globalised world: Michael Porter on the microeconomic foundations of the competitiveness of nations, regions, and firms. J Int Bus Stud 37:163-175

Steinberger JK, Krausmann F (2011) Material and energy productivity. Environ Sci Technol 45:1169-1176. doi:10.1021/es1028537

Syverson C (2011) What determines productivity? J Econ Lit 49:326-365

Thompson ER (2003) A grounded approach to identifying national competitive advantage: a preliminary exploration. Environ Plan A 35:631-657. doi:10.1068/a35110

Thompson ER (2004) National competitiveness: a question of cost conditions or institutional circumstances? Br J Manag 15:197-218. doi:10.1111/j.1467-8551.2004.00415.x

Tietenberg T (2000) Environmental and natural resource economics. Routledge, New York, USA

Tilton JE (2001) Depletion and the long-run availability of mineral commodities. Min Miner Sustain Dev $14: 1-173$

UN (1992) Agenda 21. United Nations Conf Environ Dev Rio Janerio, Brazil, 3 to 14 June 1992. doi:10. 1007/s11671-008-9208-3 
UNEP IRP (2011) Decoupling: natural resource use and environmental impacts from economic growth, Nairobi

UNEP IRP (2014) Decoupling 2-technologies, opportunities and policy options, Nairobi

UNEP IRP (2016) Global Material Flows and Resource Productivity. Assessment Report for the UNEP International Resource Panel. United Nations Environment Programme, Nairobi

UNIDO (2011) Industrial energy efficiency and competitiveness. Working paper 05/2011. Vienna, Austria

Van Der Voet E, Oers L, Nikolic I (2005) Dematerialization-not just a matter of weight. J Ind Ecol 8:121-137

Vanberg V, Kerber W (1994) Institutional competition among jurisdictions: an evolutionary approach. Const Polit Econ 5:193-219. doi:10.1007/BF02393147

Voinescu R, Moisoiu C (2015) Competitiveness, theoretical and policy approaches. Towards a more competitive EU. Proc Econ Financ 22:512-521. doi:10.1016/S2212-5671(15)00248-8

Wagner J (2007) Exports and productivity: a survey of the evidence from firm-level data. World Econ 30:60-82. doi:10.1111/j.1467-9701.2007.00872.x

Walz R (2011) Employment and structural impacts of material efficiency strategies: results from five case studies. J Clean Prod 19:805-815. doi:10.1016/j.jclepro.2010.06.023

WBCSD (2010) Vision 2050 - the new agenda for business. World Business Council for Sustainable Development. doi:10.1111/j.1530-9290.2009.00117.x

Wei H, Shenghui C, Yarime M et al (2015) Improving urban metabolism study for sustainable urban transformation. Environ Technol Innov 4:62-72. doi:10.1016/j.eti.2015.04.004

Wiedmann TO, Schandl H, Moran D (2015) The footprint of using metals: new metrics of consumption and productivity. Environ Econ Policy Stud 17:369-388. doi:10.1007/s10018-014-0085-y

World Bank, UN (2010) Natural hazards, unnatural disasters-the economics of effective prevention. doi:10.1596/978-0-8213-8050-5

World Bank (2015) Resource efficiency—cross-cutting advisory solutions. Washington, DC

Zhang P, London K (2013) Towards an internationalized sustainable industrial competitiveness model. Compet Rev An Int Bus J Inc J Glob Compet 23:95-113. doi:10.1108/10595421311305325 